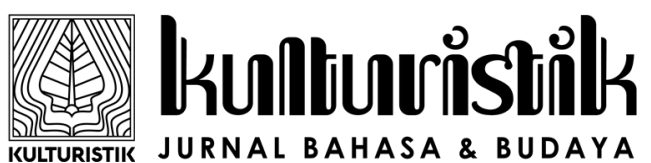

Vol. 2, No. 2, Juli 2018, 136-143

Available Online at https://ejournal.warmadewa.ac.id/index.php/kulturistik DOI: dx.doi.org/10.22225/kulturistik.2.2.726

\title{
PEMAKAIAN BAHASA INDONESIA (EJAAN) DALAM SURAT RESMI/DINAS KE LUAR DESA KESIMAN KERTALANGU KECAMATAN DENPASAR TIMUR DENPASAR
}

\author{
I Nengah Mileh \\ Universitas Warmadewa \\ milehmenuri@gmail.com
}

\begin{abstract}
ABSTRAK
Penelitian ini berjudul "Pemakaian Bahasa Indonesia (Ejaan) dalam Surat Resmi/Dinas ke luar Desa Kesiman Kertalangu, kecamatan Denpasar Timur, Denpasar”. Pemakaian bahasa Indonesia, khususnya pemakaian ejaan dalam surat resmi/dinas keluar Desa Kesiman Kertalangu, kecamatan Denpasar Timur Denpasar, masih banyak ditemukan kesalahan. Dalam penelitian ini, yang menjadi objek kajian, yaitu mengenai kesalahan pemakaian ejaan bahasa Indonesia. Dalam penelitian ini digunakan metode simak dan teknik catat untuk pengumpulan data, metode kualitatif deskriptif sinkronis digunakan untuk menganalisis data dibantu dengan teknik induktif, dan metode informal digunakan untuk penyajian hasil dibantu dengan teknik induktif. Dalam penelitian ini ditemukan beberapa jenis kesalahan pemakaian ejaan. Kesalahan ejaan yang ditemukan dalam surat resmi/ dinas ke luar desa Kesiman Kertalangu antara lain::kesalahan tanda titik (.), tanda koma (,), tanda hubung (-), tanda garis miring (/), tanda titik dua (:), dan penulisan huruf besar/ kapital.
\end{abstract}

Kata kunci: surat, komunikasi, ejaan

\begin{abstract}
[Title: The Use of Indonesian Language (Spelling) in the Official Outgoing Letters of Kesiman Kertalangu Village, district of Denpasar Timur, Denpasar]. The use of Indonesian language, especially the use of spelling in the official outgoing letters of Kesiman Kertalangu Village, district of Denpasar Timur, Denpasar, is still a lot of mistakes. In this research, the object of research is the spelling errors in Indonesian language. This research applied observation method and note-taking technique to collect the data, synchronic descriptive qualitative method was used to present the result of the analisis combined with inductive technique. In this research, some spelling errors were found. The errors found in the official outgoing letters of Kesiman Kertalangu village are error in using final stop (.), comma (,), hyphen (-), a slash (/), a colon (:), and error in using capital letters.
\end{abstract}

Keywords: letter, communication, spelling

\section{PENDAHULUAN}

Surat merupakan sarana untuk menyampaikan informasi tertulis pada pihak lain (Sumantri, 1978). Informasi itu dapat berupa pemberitahuan, perminataan, buah pikiran dan lain-lain. Sebagai sarana komunikasi tertulis, surat memiliki kelebihan dibandingkan dengan alat komunikasi lainnya. Dikatakan demikian, 
mengingat surat menjadi bukti nyata hitam di atas putih.

Di samping itu, surat sebagai sarana komunikasi resmi memiliki beberapa fungsi antara lain (1) sebagai alat bukti tertulis (hitam di atas putih) terutama surat-surat perjanjian, (2) sebagai alat pengingat karena surat dapat diarsipkan dan dapat dilihat lagi jika diperlukan, (3) sebagai bukti sejarah, seperti pada suratsurat tentang perubahan dan perkembangan suatu instansi, (4) sebagai pedoman kerja, seperti surat putusan atau surat instruksi, (5) sebagai duta atau wakil penulis untuk berhadapan dengan lawan bicaranya, dan (6) sebagai jaminan keamanan, misalnya surat jalan. (Arifin, 1987)

Informasi yang ingin disampaikan oleh pengirim surat akan sampai kepada penerima surat jika bahasa yang digunakan benar. Oleh karena itu, setiap pengonsep surat resmi dituntut untuk terampil menggunakan bahasa Indonesia yang baik dan benar. Keterampilan menggunakan bahasa Indonesia yang baik dan benar dalam surat resmi bukanlah hal yang mudah. Banyak hal yang harus dikuasai, ditaati, dan dilakukan untuk dapat terampil berbahasa Indonesia.

Berdasarkan uraian di atas, ada permasalahan yang perlu diteliti pada pemakaian bahasa Indonesia dalam surat resmi/dinas keluar Desa Kesiman Kertalangu, kecamatan Denpasar Timur, Denpasar. Rumusan masalahnya, yaitu sebagai berikut. Bagaimanakah pemakaian ejaan bahasa Indonesia dalam surat/ dinas keluar Desa Kesiman Kertalangu, kecamatan Denpasar Timur Denpasar?

\section{METODE}

Penelitian ini menggunakan metode dan teknik sebagai berikut (1) metode dan teknik pengumpulan data, (2) metode dan teknik analisis data, dan (3) metode dan teknik penyajian hasil analisis. Pengumpulan data dalam penelitian ini dilakukan dengan metode simak atau observasi (Sudaryanto, 1986: 41). Metode simak ini dibantu dengan teknik catat. Setiap data dicatat secara ortografis dalam sebuah buku catatan yang telah disiapkan terlebih dahulu. Data diperoleh dengan cara menyimak pemakaian bahasa Indonesia pada surat resmi/dinas keluar Desa Kesiman Kertalangu, Denpasar timur. Dalam penelitian ini surat yang dijadikan sampel penelitian adalah surat ke luar pada bulan Mei dan Juni 2017. Jumlah surat ke luar pada Mei 2017 sebanyak 6 surat dan pada Juni 2017 sebanyak 13 surat. Mengingat jumlah surat ke luar tidak banyak maka semua surat ke luar pada Mei dan Juni 2017 dijadikan sampel penelitian.

Data yang dikumpulkan dari surat-surat resmi ke luar Desa Kesiman Kertalangu, Denpasar Timur, Denpasar bersifat kekinian (tahun 2017). Dengan demikian, metode yang dipakai dalam menganalisis, yaitu metode deskriptif sinkronis. Teknik analisis dilakukan secara induktif, yaitu (Hadi, 1973: 44). Teknik induktif ialah cara penyajian dengan mengemukakan hal-hal yang bersifat khusus terlebih dahulu kemudian ditarik suatu simpulan yang bersifat umum (Hadi, 1973: 43).

Hasil analisis disajikan dengan metode informal. Metode informal, yaitu suatu cara penyajian hasil analisis atau kaidah dengan menggunakan kata-kata (Sudaryanto, 1986: 62). Sebagai pendukung metode formal digunakan teknik induktif untuk penyajian hasil analisis.

Teknik induktif, yaitu cara penyajian dengan mengemukakan hal-hal yang bersifat khusus kemudian ditarik simpulan yang bersifat umum (Hadi, 1973: 43). 
Vol. 2, No. 2, Juli 2018, 138

Available Online at https://ejournal.warmadewa.ac.id/index.php/kulturistik

DOI: dx.doi.org/10.22225/kulturistik.2.2.726

\section{PEMBAHASAN}

Pada bab ini akan diuraikan secara rinci mengenai kesalahan pemakaian ejaan dan perbaikannya sesuai dengan kaidah ejaan bahasa Indonesia. Penelitian ini menganalisis kesalahan pemakaian ejaan pada surat resmi/dinas ke luar desa Kesiman Kertalangu, Denpasar Timur Denpasar. Penelitian ini berhasil menemukan sejumlah data kesalahan pemakaian ejaan yang dapat dikelompokkan menjadi dua, (1) kesalahan pemakaian tanda baca dan (2) kesalahan pemakaian huruf kapital.

\section{Kesalahan Pemakaian Tanda Baca}

\section{A. Kesalahan Tanda Titik (.)}

Pemakaian tanda titik dalam surat ke luar desa Kesiman Kertalangu Denpasar Timur, banyak menyimpang dari Ejaan Bahasa Indonedia. Berikut ini diberikan beberapa contoh kesalahan pemakaian tanda titik. Tanda titik yang sering salah pemakaiannya terdapat pada penulisan nomor, lampiran, hal surat, gelar sarjana, dan singkatan. Berikut disajikan sejumlah contoh.
1) Nomor
Lampiran
Perihal
2) Nomor
Lampiran
: 005/87/V/2017/Pem.
$:-$
: Undangan Rapat Koordinasi.
Perihal$$
\text { :006/ V/2017/BPD. }
$$$$
:-
$$
: Undangan Musyawarah Desa.

Berdasarkan data di atas penulisan nomor surat masih ditemukan beberapa kesalahan. Penulisan nomor dan kode surat tidak mebutuhkan tanda titik dibelakangnya. Kesalahan yang ditemukan dalam penulisan lampiran dapat uraikan di bawah ini. Kata lampiran atau lamp. Diikuti tanda titik dua dengan menyantumkan jumlah yang dilampirkan dan nama barang yang dilampirkan, tanpa tanda baca apa pun. Jika tidak ada yang dilampirkan, kata lampiran tidak perlu dicantumkan.

Penulisan perihal atau hal sering ditemukan dalam penulisan surat dinas. Kata perihal atau hal itu bersinonim, sebaiknya dipakai kata hal saja.. Penulisan hal hendaknya diawali huruf besar sedangkan yang lainnya ditulis dengan huruf kecil. Pokok surat yang ditulis pada hal singkat dan jelas. Kesalahan lain yang ada pada penulisan hal, yaitu menggarisbawahi semua kata pada perihal atau hal secara menyeluruh sebaiknya setiap kata digarisbawahi secara terpisah. Untuk jelasnya perhatikan penulisan nomor, lampiran dan hal yang benar sebagai berikut.
1a) Nomor
Lampiran
Perihal
:005/87/2017/Pem
$:-$
1b) Nomor
: Rapat koordinasi
:005/87/2017/Pem
2a) Nomor
: Rapat koordinasi
Perihal
$: 006 / \mathrm{V} / 2017 / \mathrm{BPD}$
Nomor
2b)
Hal
: Musyawarah desa
: 006/V/2017/BPD
: Musyawarah desa 
Vol. 2, No. 2, Juli 2018, 139

Available Online at https://ejournal.warmadewa.ac.id/index.php/kulturistik DOI: dx.doi.org/10.22225/kulturistik.2.2.726

Kesalahan pemakain tanda titik pada surat resmi/dinas ke luar Desa Kesiman Kertalangu, kecamatan Denpasar Timur Denpasar, juga ditemukan pada penulisan gelar. Berdasarkan ejaan bahasa Indonesia disebutkan bahwa singkatan nama orang, gelar, sapaan, jabatan atau pangkat diikuti dengan tanda titik (Bernando, 2015). Kesalahan tersebut dapat diperhatikan berikut ini.

\begin{tabular}{ll}
\hline Salah & Benar \\
\hline I Made Suena, ST. & I Made, Suena, S.T. \\
I MADE SUENA, ST. & I MADE SUENA, S.T. \\
\hline
\end{tabular}

Singkatan nama resmi lembaga pemerintahan dan ketatanegaraan, badan atau organisasi, serta nama dokumen resmi yang terdiri atas gabungan huruf awal kata ditulis dengan huruf kapital dan tidak diikuti tanda baca (Bernando, 2015). Kesalahan pemakaian tanda titik pada singkatan nama badan atau organisasi juga ditemukan pada surat ke luar Desa Kesiman Kertalangu, kecamatan Denpasar Timur Denpasar. Jenis kesalahan itu dapat disimak berikut ini.

\begin{tabular}{ll}
\hline Salah & Benar \\
Kepada & Yth. CV Brata Semadi Production \\
Yth. CV. Brata Semadi Production & di Tempat \\
di - Tempat & \\
\hline
\end{tabular}

Kesalahan lain yang ditemukan pada surat resmi/dinas ke luar Desa Kesiman Kertalangu, kecamatan Denpasar Timur Denpasar, yaitu penulisan singkatan yang terdiri atas dua huruf. Berdasarkan aturan, singkatan yang terdiri atas dua huruf masing-masing diikuti oleh tanda titik (Bernando, 2015). Perhatikan contoh berikut.

\section{Salah}

3) Pukul : $18.30 \mathrm{Wita} \mathrm{s} / \mathrm{d}$ selesai

Menindaklanjuti serah terima kepengurusan Ketua dan anggota LPM periode 2009 s/d 2016

\section{Benar}

3a) Pukul: 18.30 s.d. selesai

Menindaklanjuti serah terima kepengurusan Ketua dan anggota LPM periode 2009 s.d. 2016

\section{B. Kesalahan Tanda Koma (,)}

Kesalahan tanda koma tidak banyak ditemukan pada surat resmi/dinas ke luar Desa Kesiman Kertalangu, kecamatan Denpasar Timur Denpasar yang dijadikan sampel penelitian ini. Pada umumnya kesalahan pemakaian tanda koma ditemukan pada kalimat penutup surat. Contohnya dapat dilihat pada kalimatkalimat berikut.

4) ..., dan atas kehadirannya kami ucapkan terima kasih.

5) Demikian surat ini kami sampaikan, atas perhatian dan kerjasamanya kami ucapkan terima kasih.

Kesalahan yang ada pada data 4) dan 5) di atas yaitu kurangnya tanda koma setelah kata kehadirannya dan kata kerjasamanya. Tidak dipakainya tanda koma pada data di atas dapat menimbulkan makna ganda bagi pembaca. Di 
Vol. 2, No. 2, Juli 2018, 140

Available Online at https://ejournal.warmadewa.ac.id/index.php/kulturistik DOI: dx.doi.org/10.22225/kulturistik.2.2.726

samping itu, pemakaian kata ganti -nya pada data 4) dan 5) tidak tepat karena surat yang ditulis umumnya ditujukan pada orang kedua, sehingga kata ganti yang tepat digunakan, yaitu kata Bapak, Ibu, Saudara, atau Anda. Dengan demikian, kalimat 4) dan kalimat 5) dapat diperbaiki menjadi sebagai berikut.

4a) ...,dan atas kehadiran Bapak/Ibu/Sdr., kami ucapkan terima kasih.

5a) Demikian surat ini kami sampaikan, atas perhatian Bapak/Ibu/Sdr., kami ucapkan terima kasih.

\section{Kesalahan Tanda Hubung (-)}

Berdasarkan data penelitian ditemukan juga pemakaian tanda hubung yang tidak tepat pada surat resmi/dinas ke luar Desa Kesiman Kertalangu, kecamatan Denpasar Timur, Denpasar. Ketidaktepatan pemakaian tanda hubung itu terjadi pada penulisan kata depan di. Sesuai ketentuan Ejaan Bahasa Indonesia, kata depan di, ke, dan dari ditulis terpisah dari kata yang mengikutinya, kecuali di dalam gabungan kata yang sudah lazim dianggap sebagai satu kata seperti kepada, dan daripada (Bernando, 2015). Di samping itu, kesalahan tanda hubung juga ditemukan pada penulisan alamat yang dituju diawali dengan yth. Untuk lebih jelasnya perhatikan contoh berikut ini.

\section{Salah}

6) Kepada

Yth.- Bapak Kepala Puskesmas Dentin II

di-

7) Kepada:

Denpasar

Yth.- Kepala Dusun se-Desa Kesiman Kertalangu

di-

$\mathrm{Te} \mathrm{mpat}$

Benar

6a) Yth. Kepala Puskesmas II

di Denpasar

7a) Yth. Kepala Dusun se-Desa Kesiman Kertalangu

di Tempat

\section{Kesalahan Tanda Garis Miring (/)}

Penggunaan Garis miring pada surat resmi/dinas ke luar Desa Kesiman Kertalangu, kecamatan Denpasar Timur Denpasar, masih ditemukan adanya penyimpangan dari ketentuan yang ada pada Ejaan Bahasa Indonesia (Bernando, 2015). Perhatikan contoh yang salah dan perbaikannya berikut ini.

\section{Salah}

8) Hari/tanggal: Senin/8 Mei 2017

9) Pukul: $18.30 \mathrm{~s} / \mathrm{d}$ selesai

10) Menindaklanjuti serah terima kepengurusan ketua dan anggota LPM periode 2009 s/d 2016 kepada ...

Benar

8a) hari, tanggal: Senin, 8 Mei 2017 
Vol. 2, No. 2, Juli 2018, 141

Available Online at https://ejournal.warmadewa.ac.id/index.php/kulturistik DOI: dx.doi.org/10.22225/kulturistik.2.2.726

9a) pukul: 18.30 s.d. selesai

10a) Menindaklanjuti serah terima kepengurusan ketua dan anggota LPM periode 2009 s.d. 2016 kepada ...

\section{E. Kesalahan TandaTitik Dua (:)}

Pemakaian tanda titik dua di dalam surat ke luar Desa Kesiman Kertalangu, Denpasar timur masih banyak ditemukan tidak sesuai dengan kaidah yang ada. Hampir pada setiap alamat surat ditemukan kesalahan pemakaian tanda titik dua. Beberapa contoh disajikan berikut ini.

11) Kepada Yth. : 1. Kelian Adat Br. Tohpati Kesiman Kertalangu

2. Kepala Dusun Br. Tohpati Kesiman Kertalangu

di-

Denpasar

12) Kepada Yth. : 1. Sekaa Teruna Br. Tohpati

2. Sekaa Teruna Br. Tangguntiti

3. Sekaa Teruna Br. Kesambi

4. Sekaa Teruna Br. Batur Sari

5. Sekaa Teruna Br. Tangtu

di-

\section{$\underline{\text { Tempat }}$}

Kata yth. merupakan kata atau ungkapan yang memerlukan pemerian. Hal ini bertentangan dengan aturan pemakaian tanda titik dua yang dituangkan pada buku Kitab Lengkap EYD yang berbunyi sebagai berikut: tanda titik dua dipakai sesudah kata atau ungkapan yang memerlukan pemerian (Bernando, 2015). Berdasarkan aturan di atas, jelas bahwa pemakaian tanda titik dua setelah kata kepada yth. Pada contoh di atas merupakan suatu kesalahan. Perbaikannya dapat diperhatikan berikut ini.

11a) Yth. 1. Kelian Adat Br.Tohpati Kesiman Kertalangu

2. Kepala Dusun Br. Tohpati Kesiman Kertalangu

di Denpasar

12a) Yth. 1. Sekaa Teruna Br. Tohpati

2. Sekaa Teruna Br. Tangguntiti

3. Sekaa Teruna Br. Kesambi

4. Sekaa Teruna Br. Batur Sari

5. Sekaa Teruna Br. Tangtu

di Tempat

Kesalahan pemakaian tanda titik dua, juga terjadi pada penulisan yang menyebutkan rincian sebagai berikut. Jika di belakang kata sebagai berikut dibubuhi tanda titik dua, maka huruf awal pada rincian di bawahnya menggunakan huruf kecil. Contoh.yang salah.

13) ..., Maka bersama ini kami sampaikan hal-hal sebagai berikut:

I. Lomba PSN...

II. Kriteria

III. Keputusan tim penilai... 
Vol. 2, No. 2, Juli 2018, 142

Available Online at https://ejournal.warmadewa.ac.id/index.php/kulturistik DOI: dx.doi.org/10.22225/kulturistik.2.2.726

Penulisan yang benar dapat dilihat pada contoh berikut ini.

13a) ..., Maka bersama ini kami sampaikan hal-hal sebagai berikut:

I. lomba PSN...;

II. kriteria; dan

III. keputusan tim penilai....

\section{Kesalahan Penulisan Huruf Besar/Kapital}

Jenis kesalahan penulisan huruf besar atau kapital cukup banyak ditemukan pada surat resmi/dinas ke luar Desa Kesiman Kertalangu, Denpasar Timur, Denpasar. Beberapa jenis kesalahan penulisan huruf besar dapat diperhatikan berikut ini.

14) ..., mengingat pentingnya acara kehadiran saudara/I sangat kami harapkan, ...

15) ..., Maka Kami Bermaksud mengundang Ketua dan Anggota Sekaa Teruna nanti Pada:...

16) ... mendampingi Bapak Walokota menghadiri undangan Bazar tersebut,...

Pada data 14) ditemukan kesalaha pemakaian kata saudara/i yang merupakan kata sapaan. Oleh karena itu, huruf pertama kata ini haruslah memakai huruf kapital. Hal ini sesuai dengan salah satu kaidah pemakaian huruf besar/kapital yang tertuang di dalam buku Kitab Lengkap EYD yang berbunyi sebagai berikut: huruf kapital dipakai sebagai huruf pertama kata penunjuk hubungan kekerabatan, seperti bapak, ibu, saudara, kakak, adik, dan paman yang digunaan dalam penyapaan atau pengacuan (Bernando, 2015). Jadi, penulisan yang betul yaitu sebagai berikut.

14a) ..., mengingat pentingnya acara kehadiran Saudara/i sangat kami harap$\operatorname{kan} \ldots$.

Di dalam buku Kitab Lengkap EYD disebutkan beberapa aturan pemakaian huruf besar/kapital. Salah satu di antaranya berbunyi: huruf kapital atau huruf besar dipakai sebagai huruf pertama kata pada awal kalimat (Bernando, 2015). Huruf pertama kata di tengah atau di akhir kalimat adalah huruf kecil, kecuali yang mengikuti aturan-aturan yang lain yang juga ditetapkan di dalam Kitab Lengkap EYD.

Aturan tersebut di atas pada umumnya telah ditaati dengan baik oleh pengonsep surat di desa Kesiman Kertalangu Denpasr Timur. Namun, ada beberapa contoh kesalahan pemakaian huruf kapital yang peneliti temukan seperti pada data 15) dan 16) di atas. Kata Maka, Kami, Bermaksud, Ketua, Anggota, Pada, dan Bazar terletak di tengah kalimat. Semua kata ini bukan nama orang, bukan nama khas dalam geografi, bukan nama suku, bukan judul karangan, dan sebagainya yang harus memakai huruf kapital di awalnya, melainkan kata biasa. Oleh karena itu, huruf pertama pada kesembilan kata tersebut di atas bukan huruf kapital, melainkan huruf kecil. Dengan demikian contoh di atas seharusnya ditulis sebagai berikut.

15a) ..., maka kami bermaksud mengundang ketua dan anggota sekaa teruna nanti pada;....

16a) ... mendampingi Bapak Walokota menghadiri undangan bazar tersebut,.... 


\section{Lisulturisiolink \\ KUITURISTIK JURNAL BAHASA \& BUDAYA}

Vol. 2, No. 2, Juli 2018, 143

Available Online at https://ejournal.warmadewa.ac.id/index.php/kulturistik

DOI: dx.doi.org/10.22225/kulturistik.2.2.726

\section{SIMPULAN}

Berdasarkan analisis di atas dapat disimpulkan sebagai berikut. Dalam analisis ini, ditemukan beberapa jenis kesalahan pemakaian ejaan pada surat resmi/ dinas ke luar Desa Kesiman Kertalangu Denpasar Timur. Jenis kesalahan pemakaian ejaan yang ditemukan meliputi: 1) kesalahan pemakaian tanda titik, terjadi pada penulisan nomor, lampiran, hal, gelar sarjana, singkatan yang terdiri atas dua huruf, dan singkatan perusahaan, 2) kesalahan pemakaian tanda koma, terjadi pada penulisan alinea penutup setelah kata sapaan orang kedua, 3) kesalahan pemakaian tanda hubung sering terjadi pada penulisan kata depan yang sebenarnya tanpa tanda hubung, 4) kesalahan pemakaian tanda garis miring, ditemukan pada penulisan singkatan yang terdiri atas dua huruf misalnya s/d dan pemisahan hari dengan tanggal misalnya Senin/8 Mei 2017, 5) kesalahan pemakaian tanda titik dua, ditemukan pada penulisan yang menyatakan rincian mengenai kegiatan/acara, 6) kesalahan penulisan huruf besar/capital, terjadi pada penulisan kata sapaan dan penulisan huruf pertama kata di tengah dan akhir kalimat adalah huruf kecil, kecuali yang mengikuti aturan-aturan lain di dalam ejaan.

\section{DAFTAR PUSTAKA}

Arifin. (1987). Penggunaa Bahasa Indonesia Dalam Surat Dinas. Jakarta: PT Melton Putra.

Bernando, R. (2015). Kitab Lengkap EYD. Yogyakarta: Diva Press.

Hadi, S. (1973). Metodologi research. Yogyakarta: Yayasan Penerbit Fakultas Psikologi Universitas Gajah Mada.

Sudaryanto. (1986). Metode linguistik. Yogyakarta: Gadjah Mada University Press.

Sumantri, M. (1978). Surat-Menyurat. Jakarta: Pusat Pembinaan dan Pengembangan Bahasa. 